\title{
Pengaruh Media Inokulum dalam Semi Ko-Enkapsulasi Sel Lactobacillus acidophilus Menggunakan Enkapsulan Matriks Eucheuma cottonii- Maltodekstrin
}

\author{
Silvia Oktavia Nur Yudiastuti ${ }^{1,3^{*}}$, Roni Kastaman ${ }^{2}$, Een Sukarminah ${ }^{2}$, dan Efri Mardawati ${ }^{2}$ \\ ${ }^{1}$ Program Studi Ilmu Pertanian, Fakultas Pertanian, Universitas Padjadjaran \\ Jalan Raya Bandung-Sumedang KM21 Jatinangor, Jawa Barat \\ ${ }^{2}$ Fakultas Teknologi Industri Pertanian, Universitas Padjadjaran \\ Jalan Raya Bandung-Sumedang KM21 Jatinangor, Jawa Barat \\ ${ }^{3}$ Program Studi Teknologi Rekayasa Pangan, Politeknik Negeri Jember \\ Jalan Mastrip Kotak Pos 164 Jember, Jawa Timur \\ *Alamat korespondensi: silvia.oktavia@polije.ac.id
}

\begin{tabular}{|c|c|}
\hline INFO ARTIKEL & ABSTRACT/ABSTRAK \\
\hline Diterima: $\quad 20-09-2021$ & \\
\hline $\begin{array}{l}\text { Direvisi: } \quad 27-12-2021 \\
\text { Dipublikasi:23-01-2022 }\end{array}$ & $\begin{array}{l}\text { The Study of Semi Co-encapsulated Matrix Eucheuma cottonii- } \\
\text { Maltodextrin as Lactobacillus acidophilus Cell Encapsulant }\end{array}$ \\
\hline
\end{tabular}

Keywords:

Bioactive compound,

Functional food,

Probiotic, Seaweed,

Sinbiotic

Kata Kunci:

Komponen bioaktif,

Pangan fungsional,

Probiotik, Rumput laut, Ssinbiotik
The function of inoculum media is to increase Lactobacillus acidophilus cells numbers before they are encapsulated. Inoculum media plays a role in maintaining the number or viability of the cells during the encapsulation process. The purpose of this research was to examine the effect of inoculum media on the encapsulation of L. acidophilus LAB cells in a semi-coencapsulated Eucheuma cottonii-maltodextrin matrix by freeze-drying and spray-drying. The research method used was descriptive with two levels of treatment. The treatment variation used consisted of two levels. The first level was $10 \%$ skimmed milk and pasteurized milk, and the second level was the encapsulation method of freeze drying and spray drying. Analysis of the morphological, physical, and microbiological properties of the encapsulated cells was concluded. The result showed that $10 \%$ skimmed milk inoculum media could increase the number of cells inside E. cottonii - maltodextrin cell capsule matrix. Pasteurized milk inoculum media maintain the cells integrity inside and outside the capsule matrix, so they have better viability than encapsulated results from $10 \%$ skimmed milk inoculum media.

Media inokulum berfungsi untuk meningkatkan jumlah sel Lactobacillus acidophilus sebelum dienkapsulasi. Media inokulum dapat turut berperan dalam mempertahankan jumlah atau viabilitas sel selama proses enkapsulasi. Tujuan penelitian ini adalah mengkaji pengaruh media inokulum dalam proses enkapsulasi sel BAL L. acidophilus dalam matriks semi ko-enkapsulasi Eucheuma cottonii - maltodekstrin menggunakan metode pengeringan beku dan metode pengeringan semprot. Metode penelitian yang digunakan adalah deskriptif. Variasi perlakuan yang digunakan terdiri dari dua taraf. Taraf pertama adalah media inokum susu skim $10 \%$ dan susu pasteurisasi, dan taraf kedua adalah metode enkapsulasi yaitu pengeringan beku dan pengeringan semprot. Hasil enkapsulasi sel, dianalisis sifat morfologis, fisik dan mikrobiologisnya. Berdasarkan hasil penelitian, diperoleh bahan media inokulum susu skim $10 \%$ dapat 
meningkatkan jumlah sel pada hasil enkapsulasi sel dalam matriks $E$. cottonii - maltodekstrin, sedangkan media inokulum susu pasteurisasi dapat mempertahankan keutuhan sel dalam matriks kapsul sel, sehingga memiliki viabilitas yang lebih baik dibandingkan hasil enkapsulasi menggunakan media inokulum susu skim $10 \%$.

\section{PENDAHULUAN}

Probiotik adalah bakteri atau khamir hidup yang dapat memberikan efek positif pada kesehatan manusia terutama pada saluran cerna manusia (Buriti et al., 2018; Hayisama-ae et al., 2014; Park \& Jeong, 2016). Aplikasi penggunaan probiotik dapat dilakukan pada rantai pengelolaan makanan dari hasil pertanian secara utuh yang dimulai dari pengelolaan hingga konsumsi pangan hasil pertanian baik yang diminum mapun dimakan. Dalam kegiatan pra panen, probiotik dapat digunakan sebagai biofertilizer atau pupuk hayati yang akan bermanfaat dalam proses fiksasi nitroogen dalam proses pertumbuhan tanaman. Efek menguntungkan komoditas pengolahan pangan dari hasil pertanian yang difortifikasi dapat meningkatkan fungsi pencernaan dan pernapasan (Ephrem et al., 2018) serta secara signifikan dapat meningkatkan imunitas tubuh dalam mengurangi penyakit menular (Cai et al., 2020; Dhar \& Mohanty, 2020; Redzwan et al., 2016; Susilo dkk., 2020; Yuen et al., Jin, 2020). Dewasa ini, probiotik bahkan dilaporkan dapat memperceat penyembuhan pasien yang terinfeksi covid-19 (Dhar \& Mohanty, 2020).

Bakteri Lactobacillus acidophilus merupakan salah satu bakteri probiotik dari golongan bakteri asam laktat (BAL) yang merupakan bakteri gram positif dan bersifat homofermentatif. Bakteri homofermentatif adalah bakteri yang menghasilkan hanya satu jenis produk sebagai hasil metabolismenya. Beberapa laporan menyatakan bahwa $L$. acidophilus dapat difortifikasi ke dalam makanan untuk meningkatkan kesehatan tubuh (Cai et al., 2020) yang dapat terdispersi dalam lemak maupun air (Vaziri et al., 2018). Perlindungan $L$. acidophilus dalam proses pengolahan pangan dapat dilakukan melalui enkapsulasi yang dapat mempertahankan sifat fungsionalnya dan memperbaiki mekanisme rilis komponen bioaktif dalam saluran cerna. L. acidophilus diharapkan dapat dimanfaatkan dalam tubuh dalam durasi waktu tertentu yang disebut dengan mekanisme rilis bioaktif. Mekanisme rilis bioaktif dapat dikendalikan menggunakan kombinasi dan konsentrasi bahan dinding enkapsulasi tertentu (Cheow et al., 2014).

Bahan yang umum digunakan sebagai enkapsulan $L$. acidophilus adalah protein, polisakarida dan hidrokoloid. Kekurangan dari penggunaan protein ketika digunakan sebagai bahan enkapsulasi adalah tidak stabil terhadap agregasi, sendimentasi dan hidrolisis (Liu et al., 2018). Bahan enkapsulan dari golongan polisakarida umum digunakan karena harganya yang terjangkau tetapi dapat meningkatkan nilai kalori produk. Hidrokoloid bersifat membentuk gel, dapat membentuk pori dan jala, serta beberapa memiliki kelebihan sebagai prebiotik, salah satunya yaitu karagenan yang merupakan sumber prebiotik dan serat pangan (Zhang et al., 2018). Enkapsulasi sel probiotik menggunakan enkapsulan prebiotik disebut dengan ko-enkapsulasi (Vaziri et al., 2018). Eucheuma cottonii merupakan salah satu jenis rumput laut yang jumlahnya melimpah di Indonesia dan mengandung kappa-karagenan yang tinggi. Spesies cottonii paling banyak mengandung karagenan dan memiliki kekuatan gel yang paling baik serta lebih tahan terhadap asam di antara marga Eucheuma (Pramita dkk., 2020). Peningkatan kekuatan pelindungan $E$. cottonii sebagai bahan enkapsulan L. acidophilus dapat digabungkan dengan polisakarida. Bahan enkapsulan golongan polisakarida yang umum digunakan adalah maltodekstrin karena maltodekstrin memiliki DE (Dextose Equivalen) yang rendah (Sao dkk., 2019) sehingga dapat menurunkan resiko peningkatan kadar kalori sel probiotik.

Gabungan matriks E. cottonii dan maltodekstrin dapat membentuk gel yang kompak (Pangestuti \& Siahaan, 2018). Matriks diartikan sebagai bahan (atau jaringan) di antara sel-sel organisme eukariotik, sering ditemukan di berbagai jaringan ikat dan umumnya berstruktur seperti jeli dalam jaringan ikat tersebut. Maltodekstin merupakan campuran monosakarida dan dekstrin, dapat berfungsi sebagai penyalut karagenan sehingga membentuk kompleks dinding enkapsulan yang lebih baik. 
Matriks E. cottonii secara potensial dapat digunakan sebagai bahan penyalut dalam enkapsulasi sel probiotik L. acidophilus karena merupakan polimer hidrokoloid yang mudah membentuk gel dan dapat menciptakan ruang untuk enkapsulasi probiotik L. acidophilus (Setijawati et al., 2018). Pemanfaatan E. cottonii yang merupakan prebiotik sebagai bahan penyalut dapat melindungi probiotik dari kondisi ekstrim dan dapat juga berfungsi sebagai substrat pertumbuhannya. Hidrogel yang terbentuk dari inokulum sel L. acidophilus dapat melindungi sel dalam proses enkapsulasi.

Pada penelitian ini, enkapsulasi L. acidophilus dilakukan dengan metode pengeringan beku dan pengeringan semprot. Kedua metode tersebut dapat menghasilkan sel dengan karakteristik kering sehingga diharapkan memiliki masa simpan yang panjang. Kedua metode tersebut juga banyak dan umum digunakan pada industri pengolahan pangan. Sel hasil enkapsulasi yang dihasilkan dari metode pengeringan beku memiliki viabilitas yang lebih baik dibandingkan dengan pengeringan semprot. Meskipun demikian, sel hasil enkapsulasi yang dihasilkan melalui pengeringan semprot memiliki biaya produksi yang lebih rendah karena waktu produksinya lebih singkat. Kekurangan metode pengeringan semprot adalah suhu yang tinggi, di atas $100^{\circ} \mathrm{C}$, dikawatirkan dapat menurunkan viabilitas sel (Reyes et al., 2018). Komposisi media inokulum dapat mempengaruhi jumlah suspensi sel, viabilitas sel terhadap proses enkapsulasi dan mekanisme rilis sel dalam saluran cerna. Media inokulum yang digunakan dalam penelitian ini adalah susu pasteurisasi yang mengandung lemak tinggi dan susu skim yang mengandung lemak lebih rendah. Susu pasteurisasi memiliki harga yang lebih rendah dari susu skim dan diharapkan dapat melindungi sel dari tingginya suhu enkapsulasi metode pengeringan semprot.

Tujuan penulisan ini adalah mengkaji pengaruh media inokulum yang digunakan dalam enkapsulasi sel L. acidophilus. Enkapsulasi dilakukan menggunakan bahan penyalut semi ko-enkapsulasi $E$. cottonii-maltodekstrin melalui metode pengeringan beku dan pengeringan semprot.

\section{BAHAN DAN METODE}

Penelitian dilakukan di Laboratorium Mikrobiologi Pangan, Departemen Teknologi Industri Pangan, Fakultas Teknologi Industri Pertanian, Universitas Padjadjaran dari Bulan Januari
2018 - Mei 2019. Metode penelitian yang digunakan adalah metode deskriptif. Perlakuan pada penelitian terdiri dari dua taraf yaitu jenis media inokulum (susu pasteurisasi (a1) dan susu skim 10\% (a2) serta jenis pengering (pengering beku ( $\left.b_{1}\right)$ dan pengering semprot (b2)). Rancangan perlakuan dalam penelitian disajikan pada Tabel 1.

Tabel 1. Rancangan perlakuan penelitian

\begin{tabular}{|c|c|c|}
\hline \multirow[b]{2}{*}{ Media inokulum } & \multicolumn{2}{|c|}{ Metode Enkapsulasi } \\
\hline & $\begin{array}{c}\text { Pengeringan } \\
\text { Beku (b1) }\end{array}$ & $\begin{array}{l}\text { Pengeringan } \\
\text { Semprot (b2) }\end{array}$ \\
\hline susu pasteurisasi ( $\left.\mathrm{a}_{1}\right)$ & $a_{1} b_{1}$ & $a_{1} b_{2}$ \\
\hline susu skim $10 \% \quad$ (a2) & $a_{2} b_{1}$ & $\mathrm{a}_{2} \mathrm{~b}_{2}$ \\
\hline
\end{tabular}

\section{Persiapan Sel L. acidophilus}

Sebelum digunakan, sel L. acidophilus (koleksi Laboratorium Mikrobiologi, Departemen Biologi, Fakultas Matematika dan Ilmu Pengetahuan Alam, Universitas Padjadjaran) diremajakan pada media agar miring MRSA (Merck) dengan suhu inkubasi $37^{\circ} \mathrm{C}$ selama 48 jam. Sel hasil peremajaan dillarutkan menggunakan $\mathrm{NaCl}$ 0,85\%, konsentrasi sel diukur berdasarkan kekeruhan larutan Mc Farland 3 pada $\lambda=600 \mathrm{~nm}$ dan absorbansi $\pm 0,616$ yang setara dengan jumlah koloni 3,0 $\times 10^{8} \mathrm{CFU} / \mathrm{ml}$ pada spektrofotometer.

\section{Persiapan Bahan Penyalut}

Bahan penyalut yang digunakan adalah kombinasi $50 \%$ bubur rumput laut ( $E$. cottonii) (merek dagang KATONI produksi UD. Kunjungan Pangan Bumi Nusantara, Depok, Jawa Barat) dan 50\% maltodekstrin DE20 (b/b). Rumput laut basah dihaluskan menggunakan blender kecepatan tinggi dengan konsentrasi 50\% hingga menjadi bubur rumput laut. Selanjutnya dipasteurisasi pada suhu $62,5^{\circ} \mathrm{C}$ selama 15 menit. Bubur rumput laut hasil pasteurisasi kemudian ditambahkan dengan maltodekstrin dengan porsi yang sama dengan bagian bubur rumput laut 1: 1 (v/v)

\section{Inokulasi Sel L. acidophilus}

Media inokulum yang digunakan dalam penelitian adalah susu pasteurisasi (a1) dan susu skim $10 \%$ (a2) (b/v). Sebanyak 10\% sel L. acidophilus yang telah dilarutkan dalam $\mathrm{NaCl}$ 0,85\% diinokulasikan ke dalam masing - masing perlakuan media inokulum (v/v). Inkubasi dalam media inokulum dilakukan selama 4 jam pada suhu $40^{\circ} \mathrm{C}$. 


\section{Enkapsulasi Sel}

Enkapsulasi dimulai dengan melarutkan sel $L$. acidophilus yang sudah diinokulasi selama 4 jam dalam media inokulum ke dalam larutan bahan penyalut. Campuran bahan peyalut dengan sel $L$. aidophilus hasil inokulasi disebut dengan suspensi sel L. acidophilus. Metode enkapsulasi yang digunakan adalah pengeringan beku dan pengeringan semprot. Suspensi sel didiamkan pada suhu $4^{\circ} \mathrm{C}$ selama 2 jam untuk selanjutnya dienkapsulasi. Enkapsulasi dengan metode pengeringan beku dimulai dengan menyimpan suspensi sel pada lemari beku dengan suhu $-60^{\circ} \mathrm{C}$ selama $18-24$ jam, kemudian dikering bekukan menggunakan pengering beku pada suhu $40^{\circ} \mathrm{C}$ selama 48 jam pada tekanan vakum $0,050 \mathrm{mBar}$ (Yudiastuti et al., 2019). Enkapsulasi dengan pengeringan semprot dilakukan menggunakan mesin pengering semprot (Buchi B-290) dengan suhu inlet $100^{\circ} \mathrm{C}$ dan suhu outlet $75^{\circ} \mathrm{C}$ dengan laju alir 20 $\mathrm{g} /$ menit.

\section{Pengujian Jumlah Sel BAL dan Viabilitas Selnya}

Pengujian jumlah sel dilakukan menggunakan metode BAM (Bacteriological Analyctical Manual) (Yudiastuti et al., 2019). Sebanyak $1 \mathrm{ml}$ sampel dilarutkan dalam $9 \mathrm{ml} 0,85 \%$ larutan $\mathrm{NaCl}$ fisiologis, diencerkan hingga $10^{-9}$ secara aseptis. Masing-masing tabung pada tiga pengenceran terakhir dituangkan sebanyak $1 \mathrm{ml}$ ke dalam cawan petri steril. Tuang medium MRS dan tambahkan 0,5\% asam asetat glasial sebanyak $12-15 \mathrm{ml}$ ke dalam cawan petri, kemudian diinkubasi pada suhu $37^{\circ} \mathrm{C}$ selama 48 jam. Viabilitas sel dihitung menggunakan persamaan sebagai berikut (Sukarminah et al., 2017):

$$
\text { Viabilitas sel }(\%)=\frac{\text { Jumlah sel hasil enkapsulasi }}{\text { Jumlah sel dalam suspen`si sel }} \times 100 \%
$$

Pengamatan Morfologis Hasil Enkapsulasi dan Rendemen Hasil Enkapsulasi

Morfologi partikel sel L. acidophilus yang dienkapsulasi diamati menggunakan Scanning Electron Microscope (SEM S-4800, Hitachi, Japan) (Vaziri et al., 2018). Tegangan percepatan adalah 10 $\mathrm{kV}$, sampel ditempelkan diatas cincin plat tembaga yang selanjutnya dilapisi emas untuk selanjutnya diamati menggunakan SEM. Rendemen hasil enkapsulasi adalah perbandingan berat antara sel yang sudah dienkapsulasi dengan berat sebelum enkapsulasi, dihitung menggunakan persamaan (Sukarminah et al., 2017):

$$
\text { Rendemen enkapsulasi }(\%)=\frac{\text { Berat Hasil enkapsulasi }}{\text { Berat suspensi sel }} \times 100 \%
$$

\section{HASIL DAN PEMBAHASAN}

\section{Morfologis Hasil Enkapsulasi sel L. acidophilus}

Setiap sel L. acidophilus yang telah dienkapsulasi diamati penampang morfologinya menggunakan dengan metode SEM (Gambar 1). Hal tersebut bertujuan untuk melihat ukuran sel hasil enkapsulasi yang telah dienkapsulasi serta mengetahui efek perlindungan matriks gabungan $E$. cottonii - maltodekstrin. Media inokulum susu pasteurisasi memberikan lapisan lunak pada matriks dinding kapsul, sedangkan media inokulum susu skim memperkeras permukaan dinding kapsul. Pada Gambar 1 dapat dilihat bahwa hasil enkapsulasi dengan media inokulum susu pasteurisasi (a1) diselaputi lemak. Lemak lebih bersifat non polar, kandungan lemak dalam susu pasturisasi yang lebih tinggi membuat lemak lebih tertarik ke lapisan paling luar dari matriks kapsul. E. cottonii dan maltodekstrin memiliki sifat yang sama - sama polar
(Zhang et al., 2018), sehingga akan lebih kuat tertarik ke dalam inti sel $L$. acidophilus yang disalutnya karena $L$. acidophilus memiliki sifat yang lebih cenderung polar. Akibatnya, campuran matriks yang mengandung lebih sedikit lemak akan memiliki permukaan yang tampak kering seperti ditunjukkan pada perlakuan media inokulum susu skim 10\% (a $\mathrm{b}_{1}$ dan $\mathrm{a}_{2} \mathrm{~b}_{2}$ ).

Pada kombinasi perlakuan media inokulum susu skim $10 \%$ dengan metode pengeringan beku, tampak sel L. acidophilus berhamburan keluar matriks kapsul. Sedangkan pada kombinasi perlakuan media inokulum susu skim 10\% dengan metode pengeringan semprot, tampak matriks kapsul menciut, meskipun masih dapat mempertahankan sel L. acidophilus dalam matriks kapsul.

Durasi enkapsulasi yang lebih lama pada metode pengeringan beku, ternyata memberikan pengaruh pada kenampakan kapsul sel yang lebih rapuh dibandingkan metode pengeringan semprot. 
Meskipun dilakukan pada suhu di atas $100^{\circ} \mathrm{C}$, tetapi durasi enkapsulasi dengan pengeringan semprot lebih cepat $90 \%$ dari pengeringan beku. Durasi pengeringan beku untuk $2 \mathrm{~L}$ suspensi sel $L$. acidophilus adalah $48-50$ jam, sedangkan pengeringan semprot berlangsung selama $10-50$ menit untuk volume suspensi yang sama. Pengeringan beku dapat mempertahankan kualitas

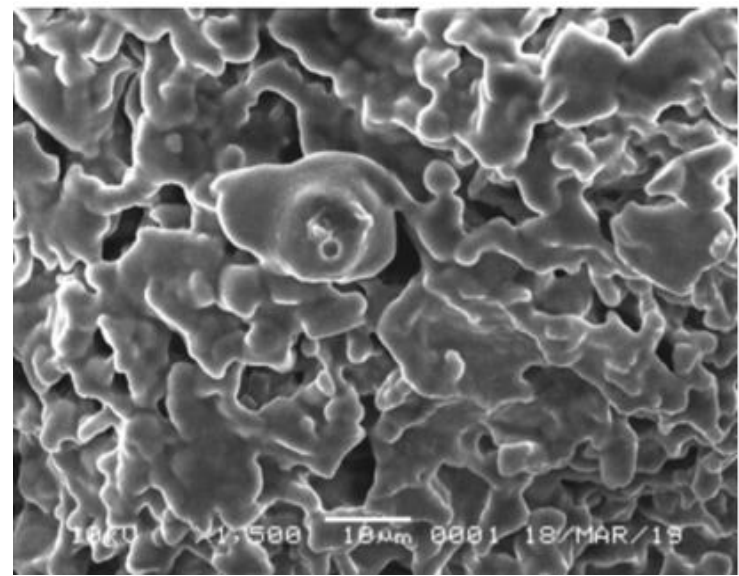

a $b_{1}$ (susu pasteurisasi dan pengering beku)

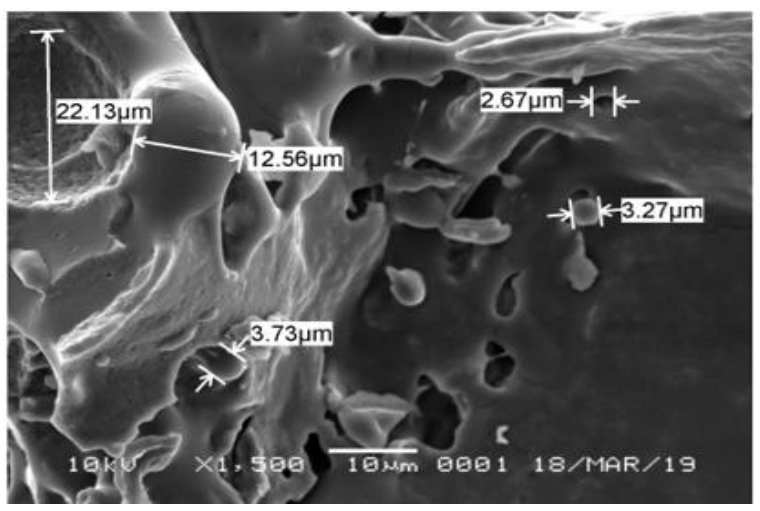

$\mathrm{a}_{2} \mathrm{~b}_{1}$ (susu skim 10\% dan pengering beku) produk sebab kandungan air bahan tidak berada dalam kondisi cair, sehingga memperkecil resiko degradasi komponen bioaktif, tetapi sublimasinya berlangsung lama sebab dilakukan pada suhu yang sangat rendah (Ahmed et al., 2013; Mu et al., 2018). Ukuran sel dan ukuran kapsul yang menjadi matriks kapsul sel L. acidophilus, disajikan pada Tabel 2.

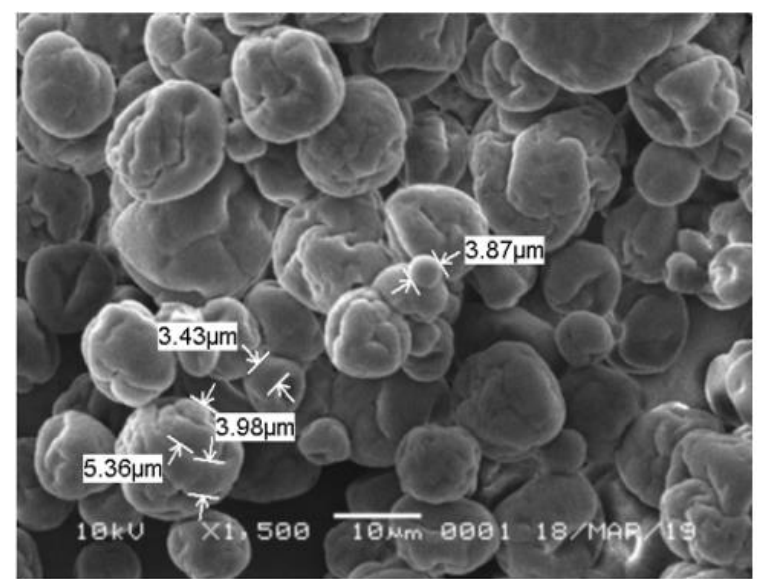

$\mathrm{a}_{1} \mathrm{~b}_{2}$ (susu pasteurisasi dan pengering semprot)

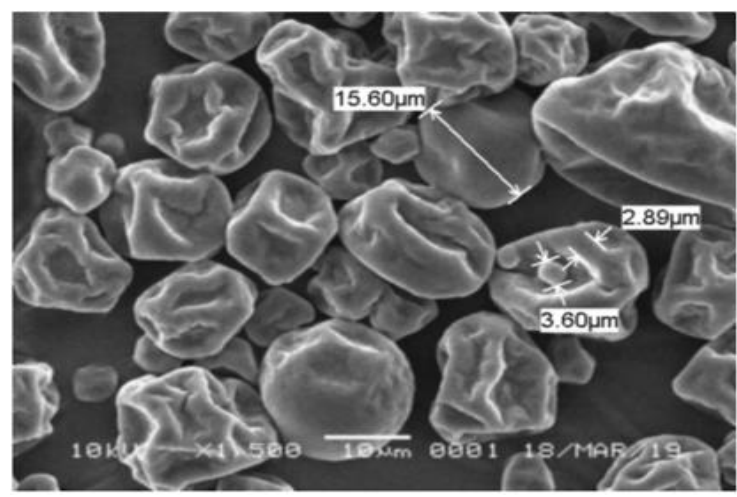

a2b2 (susu skim 10\% dan pengering semprot)

Gambar 1. Analisis SEM sel L. acidophilus hasil enkapsulasi

Tabel 2. Ukuran sel L. acidophilus dan Kapsul E. cottonii-Maltodekstrin hasil penelitian

\begin{tabular}{lcc}
\hline \multirow{2}{*}{ Perlakuan } & \multicolumn{2}{c}{ Ukuran $(\mu \mathrm{m})$} \\
\cline { 2 - 3 } & Sel L. acidophilus & $\begin{array}{c}\text { Mikro kapsul E. cottonii - } \\
\text { Maltodekstrin }\end{array}$ \\
\hline a1b1 (susu pasteurisasi dan pengering beku) & 3,4 & 7,1 \\
a1b2 (susu pasteurisasi dan pengering semprot) & 3,4 & 5,3 \\
a2b1 (susu skim 10\% dan pengering beku) & 3,4 & 22,1 \\
a $\mathrm{b}_{2}$ (susu skim 10\% dan pengering semprot) & 3,4 & 15,6 \\
\hline
\end{tabular}

Ukuran sel L. acidophilus dalam penelitian ini memiliki ukuran yang sama berdasarkan hasil uji SEM pada Gambar 1 yaitu 3,4 $\mu \mathrm{m}$. Ukuran kapsul paling kecil adalah perlakuan media inokulum susu pasteurisasi dengan metode pengeringan semprot $\left(a_{1} b_{2}\right)$, dan yang terbesar adalah perlakuan metode inokulum susu skim $10 \%$ dengan metode enkapsulasi pengeringan beku (a2 $\left.b_{1}\right)$. Ukuran kapsul hasil pengeringan semprot lebih kecil dibandingkan hasil enkapsulasi dengan metode pengeringan beku, 
karena enkapsulasi dengan pengeringan semprot dilakukan melalui atomizer yang menyebabkan ukuran partikel bahan menjadi lebih kecil dan seragam. Ukuran kapsul hasil inokulasi susu pasteurisasi lebih kecil dibandingkan hasil inokulasi susu skim 10\%, karna lemak dalam susu pasteurisasi lebih tinggi, dimana lemak memiliki sifat non polar. Sifat kepolaran yang rendah dapat menolak air, sehingga hasil enkapsulasi akan lebih hidrofobik dan higroskopis yang menyebabkan dinding kapsul dengan bahan penyalut susu pasteurisasi lebih tebal dibandingkan susu skim $10 \%$ yang mengandung lebih sedikit lemak.

\section{Karakteristik Fisik dan Mikrobiologis Hasil Enkapsulasi Sel L.acidophilus}

Pada akhir proses enkapsulasi, residu gumpalan atau serbuk enkapsulasi di kerok dari labu pengeringan pada pengering beku dan chamber penampung pada pengering semprot untuk mendapatkan nilai rendemen enkapsulasi lebih akurat. Meskipun demikian, sangat sulit untuk memperoleh seluruh residu yang tersisa, karena hasil enkapsulasi menempel dengan kuat pada labu pengeringan atau menempel pada bagian - bagian pengering semprot.

Pada pengering beku, hasil enkapsulasi ditumbuk dengan mortar dan diayak dengan saringan mesh 80 untuk menyeragamkan ukuran partikel hasil enkapsulasi sel. Penumbukan dan pengayakan membuat lebih banyak hasil enkapsulasi tersisa pada dinding mortar dan pengayak. Rendemen hasil enkapsulasi sel $L$. acidophilus dengan metode pengeringan beku dan pengeringan semprot, dapat dilihat pada Tabel 3 .

Tabel 3. Rendemen hasil, jumlah sel dan viabilitas enkapsulasi sel L.acidophilus

\begin{tabular}{cccc}
\hline Perlakuan & Rendemen (\%) & Jumlah Sel (CFU/g) & Viabilitas (\%) \\
\hline $\mathrm{a}_{1} \mathrm{~b}_{1}$ & $21,01 \pm 2 \%$ & $\log 11,9 \pm 0,05$ & $93,40 \pm 0,5$ \\
$\mathrm{a} 1 \mathrm{~b}_{2}$ & $16,71 \pm 1 \%$ & $\log 11,8 \pm 0,3$ & $92,73 \pm 2,7$ \\
$\mathrm{a} 2 \mathrm{~b}_{1}$ & $21,10 \pm 2 \%$ & $\log 12,3 \pm 0,2$ & $92,10 \pm 3,6$ \\
$\mathrm{a}_{2} \mathrm{~b}_{2}$ & $18,39 \pm 0,6 \%$ & $\log 12,0 \pm 0,05$ & $90,71 \pm 1,6$ \\
\hline
\end{tabular}

Keterangan : $\quad a_{1} b_{1}=$ susu pasteurisasi dan pengering beku; $a_{1} b_{2}=$ susu pasteurisasi dan pengering semprot; $a_{2} b_{1}=$ susu skim $10 \%$ dan pengering beku; $\mathrm{a}_{2} \mathrm{~b}_{2}=$ susu skim $10 \%$ dan pengering semprot)

Berdasarkan Tabel 3, perlakuan metode enkapsulasi pengeringan beku, memiliki rendemen yang lebih besar dibandingkan perlakuan dengan pengeringan semprot. Salah satu kelemahan metode pengeringan semprot adalah menempelnya produk hasil pengeringan dalam saluran dan ruang pengering yang dapat menurunkan rendemen hasil produk (Hariyadi, 2017; Seveline, 2017).

Jumlah sel dari hasil enkapsulasi dengan media inokulum susu pasteurisasi lebih rendah dibandingkan menggunakan media inokulum susu skim $10 \%$, tetapi viabilitasnya lebih tinggi. Hal tersebut menunjukkan susu pasteurisasi sebagai media inokulum berpengaruh positif dalam melindungi sel selama proses enkapsulasi, baik melalui metode pengeringan beku yang memiliki durasi lebih lama, maupun metode pengeringan semprot yang menggunakan suhu di atas $100^{\circ} \mathrm{C}$.

Prinsip pengeringan beku adalah penurunan suhu produk hingga produk dalam fasa padat karena kandungan air dalam bahan membeku, selanjutnya dilakukan penurunan tekanan sekitar produk sehingga es dalam bahan menyumblim menjadi gas (Cąbuk \& Harsa, 2015). Proses sublimasi dilakukan pada suhu dan tekanan di bawah titik triplet air. Titik triplet air berada pada suhu $273,16^{\circ} \mathrm{K}$ dan tekanan 6,11 mbar (4,58 Torr) (Fissore \& Pisano, 2015). Kondisi ini dicapai pada saat ketiga fasa air (padat, cair dan gas) berada dalam keadaan setimbang. Sublimasi air bukan dalam fasa cair menyebabkan komponen bioaktif dapat lebih stabil (CalderónOliver et al., 2017).

Kandungan lemak yang lebih tinggi pada media inokulum susu pasteurisasi menyebabkan campuran larutan suspensi menjadi lebih tidak polar (Vaziri et al., 2018). Hal tersebut menyebabkan kombinasi bahan penyalut E. cottonii-maltodekstri lebih tertarik ke inti sel L. acidophilus yang ketiganya memiliki sifat yang sama - sama polar. Akibatnya lemak menyeliputi bagian luar matriks kapsul, melindungi sel dari proses mekanis enkapsulasi sel. Kelebihan lain dari lemak yang menyeliputi dinding sel matriks enkapsulasi adalah sifatnya yang non polar, menyebabkan antara partikel kapsul tidak akan membentuk agregat yang dapat menyebabkan sel berukuran lebih besar seperti perlakuan media inokulum susu skim $10 \%$ pada proses pengeringan beku (Gambar 1). 


\section{SIMPULAN}

Peningkatan viabilitas $L$. acidophilus sebagai bahan komponen bioaktif dalam bahan pangan dipengaruhi oleh jenis media inokulum dan metode enkapsulasi yang digunakan. Media inokulum memberikan pengaruh dalam melindungi sel selama proses enkapsulasi sel. Kandungan lemak yang lebih tinggi dalam media inokulum susu pasteurisasi melapisi bagian luar kapsul dari proses mekanis selama enkapsulasi sel. Hal tersebut dapat mempertahankan jumlah sel dalam produk akhir enkapsulasi dan meningkatkan nilai viabilitas selnya.

Penggunakan susu pasteurisasi sebagai media inokulum dapat melindungi inti sel $L$. acidophilus lebih baik pada metode enkapsulasi dengan pengeringan semprot yang menggunakan suhu tinggi (di atas $100^{\circ} \mathrm{C}$ ). Gabungan bahan enkapsulasi $E$. cottonii - Maltodekstrin dapat memberikan perlindungan yang baik, keduanya sama - sama bersifat polar sehingga dapat melindungi inti lebih baik.

\section{UCAPAN TERIMA KASIH}

Terima kasih kepada Ketua Laboratorium dan Pranata Laboratorium Pendidikan Laboratorium Mikrobiologi Pangan, Kimia pangan, Keteknikan Pengolahan Pangan Jurusan Teknologi Industri Pertanian Fakultas Teknologi Industri Pertanian dan Laboratorium Sentral Universitas Padjadjaran Jatinangor serta Laboratorium Instrumen Jurusan Kimia Fakultas Matematika dan Ilmu Pengetahuan Alam Universitas Pendidikan Indonesia karena telah menjadi tempat dalam pelaksanaan penelitian kami.

\section{DAFTAR PUSTAKA}

Ahmed, N, J Singh, H Chauhan, PGA Anjum, and H Kour. 2013. Different drying methods: Their applications and recent advances. International Journal of Food Nutrition and Safety. 4(1), 34-42.

Buriti, FCA, R Bedani, and SMI Saad. 2018. Probiotic and prebiotic dairy desserts. In Probiotics, Prebiotics, and Synbiotics. doi: 10.1016/B9780-12-802189-7.00023-X

Cąbuk, B, and ST Harsa. 2015. Improved viability of Lactobacillus acidophilus NRRL-B 4495 during freeze-drying in whey proteinpullulan microcapsules. Journal of Microencapsulation. 32(3), 300-307. doi:

\subsection{9/02652048.2015.1017618}

Cai, Y, A Sounderrajan, and L Serventi. 2020. Water kefir: A review of its microbiological profile, antioxidant potential and sensory quality. Acta Scientifci Nutritional Health. 4(6), 1017. doi: 10.31080/asnh.2020.04.0706

Calderón-Oliver, M, R Pedroza-Islas, HB EscalonaBuendía, J Pedraza-Chaverri, and E PonceAlquicira. 2017. Comparative study of the microencapsulation by complex coacervation of nisin in combination with an avocado antioxidant extract. Food Hydrocolloids. 62 49-57. doi: 10.1016/j.foodhyd.2016.07.028

Cheow, WS, TY Kiew, and K Hadinoto. 2014. Controlled release of Lactobacillus rhamnosus biofilm probiotics from alginate-locust bean gum microcapsules. Carbohydrate Polymers. 103: 587-595. doi: 10.1016/j.carbpol.2014.01.036

Dhar, D, and A Mohanty. 2020. Gut microbiota and Covid-19- possible link and implications. Virus Research, 285(April): 198018. doi: 10.1016/j.virusres.2020.198018

Ephrem, E, A Najjar, C Charcosset, and H GreigeGerges. 2018. Encapsulation of natural active compounds, enzymes, and probiotics for fruit juice fortification, preservation, and processing: An overview. Journal of Functional Foods. 48(June): 65-84. doi: 10.1016/j.jff.2018.06.021

Fissore, D, and R Pisano. 2015. Computer-aided framework for the design of freeze-drying cycles: optimization of the operating conditions of the primary drying stage. Processes. 3(2): 406-421. doi: 10.3390/pr3020406

Hariyadi, P. 2017. Pengering semprot: Aplikasinya untuk mikroenkapsulasi kompoenen fungsional. Foodreview Indonesia. XII(5): 5053.

Hayisama-ae, W, D Kantachote, D Bhongsuwan, U Nokkaew, and C Chaiyasut. 2014. A potential synbiotic beverage from fermented red seaweed (Gracilaria fisheri) using Lactobacillus plantarum DW12. International Food Research Journal. 21(5): 1789-1796.

Liu, H, J Gong, D Chabot, SS Miller, SW Cui, F Zhong, and Q Wang. 2018. Improved survival of Lactobacillus zeae LB1 in a spray dried alginate-protein matrix. Food Hydrocolloids. 78: 100-108. doi: 10.1016/j.foodhyd.2017.07.004 
Mu, RJ, Y Yuan, L Wang, Y Ni, M Li, H Chen, and J Pang. 2018. Microencapsulation of Lactobacillus acidophilus with konjac glucomannan hydrogel. Food Hydrocolloids. 76: 42-48. doi: 10.1016/j.foodhyd.2017.07.009

Pangestuti, R, and EA Siahaan. 2018. SeaweedDerived Carotenoids. In Bioactive Seaweeds for Food Applications. doi: 10.1016/B978-012-813312-5.00005-4

Park, K, and J Jeong. 2016. Chapter 26. Kimchi (korean fermented vegetables) as a probiotic food. In Probiotics, Prebiotics, and Synbiotics. doi: 10.1016/B978-0-12-802189-7.00026-5

Pramita, S, R Karnila, dan A Diharmi. 2020. Potensi kappa karaginan rumput laut (Eucheuma cottonii) sebagai antioksidan dan inhibitor enzim $\alpha$-glukosidase. Berkala Perikanan Terubuk. 48(2): 1-10.

Redzwan, SM, R Jamaluddin, FN Ahmad, and Y Lim. 2016. Chapter 27. Probiotics as potential adsorbent of aflatoxin. In Probiotics, Prebiotics, and Synbiotics. doi: 10.1016/B9780-12-802189-7.00027-7

Reyes, V, A Chotiko, A Chouljenko, and S Sathivel. 2018. Viability of Lactobacillus acidophilus NRRL B-4495 encapsulated with high maize starch, maltodextrin, and gum arabic. Lwt. 96: 642-647. doi: 10.1016/j.lwt.2018.06.017

Sao, FPV, S Bahri, dan Indriani. 2019. Produksi maltodekstrin dari pati umbi talas (Colocasia esculenta) menggunakan enzim $\alpha$-amilase. KOVALEN: Jurnal Riset Kimia. 5(1): 68-77.

Setijawati, D, H Nursyam, and H Salis. 2018. Carrageenan the difference between PNG and KCL gel precipitation method as Lactobacillus acidophilus encapsulation material. IOP Conference Series: Earth and Environmental Science. 137(1). doi: 10.1088/1755-1315/137/1/012073

Seveline, S. 2017. Kajian pustaka teknik pengeringan semprot ( spray drying ) untuk pengawetan dan produksi probiotik. Jurnal Agroindustri. 3(April): 80-86.

Sukarminah, E, O Paulia, DM Sumanti, and E Wulandari. 2017. The effect of freeze dried Lactobacillus acidophilus culture concentration a microbiological and organoleptic characteristics of synbiotic biscuits made from sorghum flour and soybean flour. Journal of Industrial and Information Technology in Agriculture. 1(2): 36-42.

Susilo, A, CM Rumende, CW Pitoyo, WD Santoso, M Yulianti, H Kurniawan, R Sinto, G Singh, L Nainggolan, EJ Nelwan, LK Chen, A Widhani, E Wijaya, B Wicaksana, M Maksum, F Aniisa, C Olivia, M Jasirwan, dan E Yunihastuti. 2020. Coronavirus disease 2019: Tinjauan literatur terkini. Jurnal Penyakit Dalam Indonesia. 7(1), 45-67.

Vaziri, AS, I Alemzadeh, M Vossoughi, and AC Khorasani. 2018. Co-microencapsulation of Lactobacillus plantarum and DHA fatty acid in alginate-pectin-gelatin biocomposites. Carbohydrate Polymers, 199, 266-275. doi: 10.1016/j.carbpol.2018.07.002

Yudiastuti, S., Sukarmiah, E., Mardawati, E., \& Kastaman, R. (2019). Evaluation study of Lactobacillus acidophilus drying. IOP Conference Series: Earth and Enviromental Science. 250(1): doi: 10.1088/17551315/250/1/012016

Yuen, KS, ZW Ye, SY Fung, CP Chan, and DY Jin. 2020. SARS-CoV-2 and COVID-19: The most important research questions. Cell and Bioscience. 10(1): 1-5. doi: 10.1186/s13578020-00404-4

Zhang, D, M Zhang, and X Gu. 2018. Seaweedderived hydrocolloids as food coating and encapsulation agents. In Bioactive Seaweeds for Food Applications. doi: 10.1016/B978-012-813312-5.00008-X 